\title{
Unmyelinated nerve fibres in leprosy. A qualitative and quantitative study of sural nerve biopsies in 2 cases of lepromatous leprosy
}

\author{
ELLEN GIBBELS, ${ }^{*} \ddagger$ URSULA HENKE-LÜBKE* \\ \& G KLINGMÜLLER†§ \\ * Neurological Department, University of Cologne, Federal Re public \\ of Germany; †Dermatological Department, University of Bonn, \\ Federal Republic of Germany
}

\section{Accepted for publication 10 November 1987}

\begin{abstract}
Summary Since morphometric analysis of unmyelinated nerve fibres is lacking in leprosy literature, they were investigated in sural nerves of 2 lepromatous cases. Despite normal or even increased total numbers of unmyelinated axons, tentative differentiation in not-yet-myelinated axons and genuine unmyelinated fibres or their regenerates according to associated Schwann cells and fibre calibres revealed a mild to severe loss of genuine unmyelinated fibres. A predominant involvement, surpassing loss of genuine myelinated fibres, could not be stated in either case. Quantification of degenerating unmyelinated fibres, denervated Schwann cell complexes, and Schwann cell nuclei-both of the unmyelinated type-is also presented and discussed.
\end{abstract}

\section{Introduction}

Since a loss of pain and thermal sensibility with concomitant involvement of peripheral autonomic functions ${ }^{1}$ constitutes one of the first symptoms in leprosy and remains a characteristic clinical feature even in later stages of the disease, unmyelinated nerve fibres deserve special interest. Accordingly, qualitative alterations have been described by several authors, studying nerve biopsies of leprous patients by electron microscopy ${ }^{2} 9$ or using animal models of the disease. ${ }^{10}{ }^{12}$ But so far quantitative analysis of unmyelinated fibres is completely missing. There are only short remarks mostly concerning 'loss', 'reduction', 'decrease' or 'depletion', 4,6,8,9,13,14 rarely even an 'increase' or a 'prominence' is mentioned. ${ }^{8,15,16} \mathrm{Here}$, we present the results of qualitative and, more interestingly, quantitative electron microscopic studies of the unmyelinated fibre population in 2 treated cases of the lepromatous spectrum. Detailed leprological data and preliminary morphometrical results of case 1 have been published previously. ${ }^{17}$

$\S$ Professor Klingmüller has died since the submission of this paper.

$\ddagger$ Correspondence and reprint requests: Neurological Department, University of Cologne, JosephStelzmann-Str. 9, D-5000 Cologne 41. 


\section{Materials and methods}

The relevant clinical features of the 2 cases are summarized in Table 1. After informed consent whole sural nerve biopsies in both patients and in a 41 -year-old control ${ }^{17,18}$ were performed each at the ankle level. The specimens were fixed in $3.9 \%$ glutaraldehyde with $0.05 \mathrm{~m}$ phosphate buffer ( $\mathrm{pH}$ $7 \cdot 6$ ), postfixed in $2 \%$ osmium tetroxide, and embedded in epoxy. Ultrathin sections were stained with lead citrate, and examined by a PHILIPS 400 electron microscope (NS Philips, Eindhoven, The Netherlands).

Morphometric analysis of unmyelinated fibres was performed on nonoverlapping consecutive electron micrographs (initial magnification $\times 6000$, final magnification $\times 21,000$ ) of well-orientated areas of at least 4 cross-sectioned fascicles (f urther details see Table 2). Small rounded profiles with or even without mesaxon - if located excentrically or otherwise incompletely wrapped by Schwann cell processes - were considered as unmyelinated axons, when (1) a larger number of microtubules was present compared with the respective Schwann cell cytoplasm, and/or (2) when there was greater electron density of the surrounding membrane compared to that of Schwann cell plasmalemm, and/or (3) when rounded profiles exhibited lesser electron density than Schwann cell cytoplasm. ${ }^{19,20}$ In cases of doubt whether a structure was an axon or a Schwann cell process viewing the negatives through an ocular lens $(\times 9)$ was sometimes helpful to make the decision. Remaining questionable structures were not regarded as axons. Before measuring and counting the axons, the associated Schwann cell complexes were separated into 2 categories - controlled by montages of low power view electron micrographs $(\times 4725)$-according to the criteria of Ochoa \& Mair: ${ }^{21}$ (1) unmyelinated type, characterized by smaller units, built up by plate-like processes; and (2) myelinated type, characterized by larger complexes, built up by more bizarre Schwann cell processes, or complexes complementarily arranged to complexes with remyelinating axons. Since in case 1 differentiation was blurred by focal Schwann cell swelling, which rendered the criterium of

Table 1. Summary of clinical data, including results of extensive general laboratory tests.

\begin{tabular}{|c|c|c|c|c|c|}
\hline $\begin{array}{l}\text { Case and } \\
\text { biopsy } \\
\text { number }\end{array}$ & $\begin{array}{l}\text { Age, sex, } \\
\text { and geographical } \\
\text { origin }\end{array}$ & $\begin{array}{l}\text { Type of } \\
\text { leprosy* }\end{array}$ & $\begin{array}{l}\text { Duration } \\
\text { of leprosy } \\
\text { symptoms }\end{array}$ & $\begin{array}{l}\text { Duration } \\
\text { of specific } \\
\text { treatment }\end{array}$ & Clinical features \\
\hline $\begin{array}{l}\text { Case 1 } \\
\text { N38/82 }\end{array}$ & $\begin{array}{l}64 \text { years } \\
0 \\
\text { Cambodian }\end{array}$ & Lepromatous & 18 months & 2 weeks (?) & $\begin{array}{l}\text { Slight facies leontina. Smooth cutaneous } \\
\text { nodules symmetrical over whole body. } \\
\text { Radial nerves slightly enlarged. Reduc- } \\
\text { tion of pain and thermal sensibility } \dagger \\
\text { slightly in skin lesions, markedly over } \\
\text { extremities, here patchy symmetrically, } \\
\text { including sural nervearea. Muscle stretch } \\
\text { reflexes well preserved. Positive syphilis } \\
\text { reactions in serum. }\end{array}$ \\
\hline
\end{tabular}

Case $2 \quad 37$ years N39/82
Lepromatous About

4 years
7 months

Extensive erythematous macules. Radial nerves enlarged. Slight atrophy and paresis of hand and forearm muscles. Loss of pain and thermal sensibility $\dagger$ symmetrically over distal extremities including sural nerve area. Atrophic skin of feet. Muscle stretch reflexes well preserved. Chronic persistant hepatitis B.

\footnotetext{
* Classified according to clinical data and results of Lepromin-A-Test, nasal mucosal scraping, skin and nerve biopsies with special staining for acid-fast bacteria.

$\dagger$ Sensory testing by classical neurological methods.
} 
size less liable, a revision of previously communicated results ${ }^{22}$ was undertaken by complete reevaluation of case 1 with introduction of a third category: 'questionable myelinated type'. The associated unmyelinated axons were measured and counted separately using a MOP-videoplan (Kontron Electronica D-8057 Eching). Denervated Schwann cell complexes (more than 2 Schwann cell processes) and Schwann cell nuclei, both belonging to the unmyelinated type, were counted likewise.

As unmyelinated axons in Schwann cell complexes of the myelinated type most probably represent not-yet-myelinated sprouts of regenerating formerly myelinated fibres, and as an excess of miniature axons in Schwann cells of the unmyelinated type, presumably represent regenerating sprouts of original unmyelinated fibres, the total density $/ \mathrm{mm}^{2}$ or number per nerve of unmyelinated axons does not reflect the original unmyelinated fibre population..$^{23}$ According to the proposals of Ochoa \& Mair $^{21}$ we theref ore corrected the total values (1) by subtraction of all unmyelinated axons in Schwann cells of the myelinated type and in case 1 questionable myelinated type, and (2) by further subtraction of the excess (more than $21 \%)$ of miniature unmyelinated axons $(\leqq 0 \cdot 8 \mu \mathrm{m}$ diameter). The total count per nerve was calculated by extrapolation to the whole nerve area. ${ }^{19}$ Findings concerning myelinated fibres and endoneurial area were derived from a parallel still unpublished study. Attempting to elucidate a probable preferential loss of unmyelinated fibres, in contrast to previous presentations ${ }^{22}$ their corrected density was compared to the density of the presumably genuine myelinated fibre population. For the histograms, myelinated as well as unmyelinated fibre diameters were derived from fibre areas.

\section{Results}

\section{CASE 1}

Semithin and ultrathin sections revealed a well-preserved endoneurial architecture with many thinly remyelinated fibres (Figure 1). Solid and degenerated bacteria were seen in numerous macrophages (foam cell types and in many Schwann cells almost invariably associated with unmyelinated fibres) (Figure 1(a) and (b)). Here, the bacterial structures always occurred within an electron lucent halo which was often membrane-bound, exhibiting the characteristics of a phagosome, not inf requently with an electron-dense excentric rim. In some fascicles, Schwann cells were swollen, their cytoplasm exhibiting a watery appearance. Only rarely was it densely packed with filaments. Schwann cells with bacterial structures mostly contained normal-looking unmyelinated axons. Uncharacteristic qualitative changes occurred only rarely, e.g. swollen axoplasm, loss, proliferation or abnormal grouping of microtubules, neurofilament dissolution, proliferation of membraneous organelles. Many miniature axons were visible mostly in Schwann cell complexes of the unmyelinated type. Some axons were seen in an excentric position, on one side only covered by a basement membrane. Others situated more centrally occurred abutted to each other with incomplete wrapping by Schwann cell processes. Rarely, even completely isolated axon-like structures (not counted) were found, only surrounded by the basement membrane.

Quantitative analysis of myelinated fibres revealed a still normal density $/ \mathrm{mm}^{2}$ (7076) and number per nerve (6818). However, an increase of smaller $(\leqq 7 \mu \mathrm{m})$ and decrease of larger calibres was obvious (Figure 2). Density $/ \mathrm{mm}^{2}$ and number per nerve of unmyelinated axons were increased, when compared with the younger control (Table 2) and age-related values of the literature. ${ }^{19,21.24}$ But numerous unmyelinated axons were found in Schwann cells of the myelinated or questionable myelinated type (Table 2). The histogram revealed an impressing shift towards smaller calibres and a widening of the spectrum beyond $2 \cdot 4-\mu \mathrm{m}$ diameter fibres (Figure 2 ) compatible with segmental demyelination or even regeneration of not-yet-myelinated axons. After the correction (see Materials and methods) density $/ \mathrm{mm}^{2}$ and number per nerve of presumed genuine unmyelinated fibres were much lower (Table 2) but still in normal range. Likewise the percentage of degenerating 

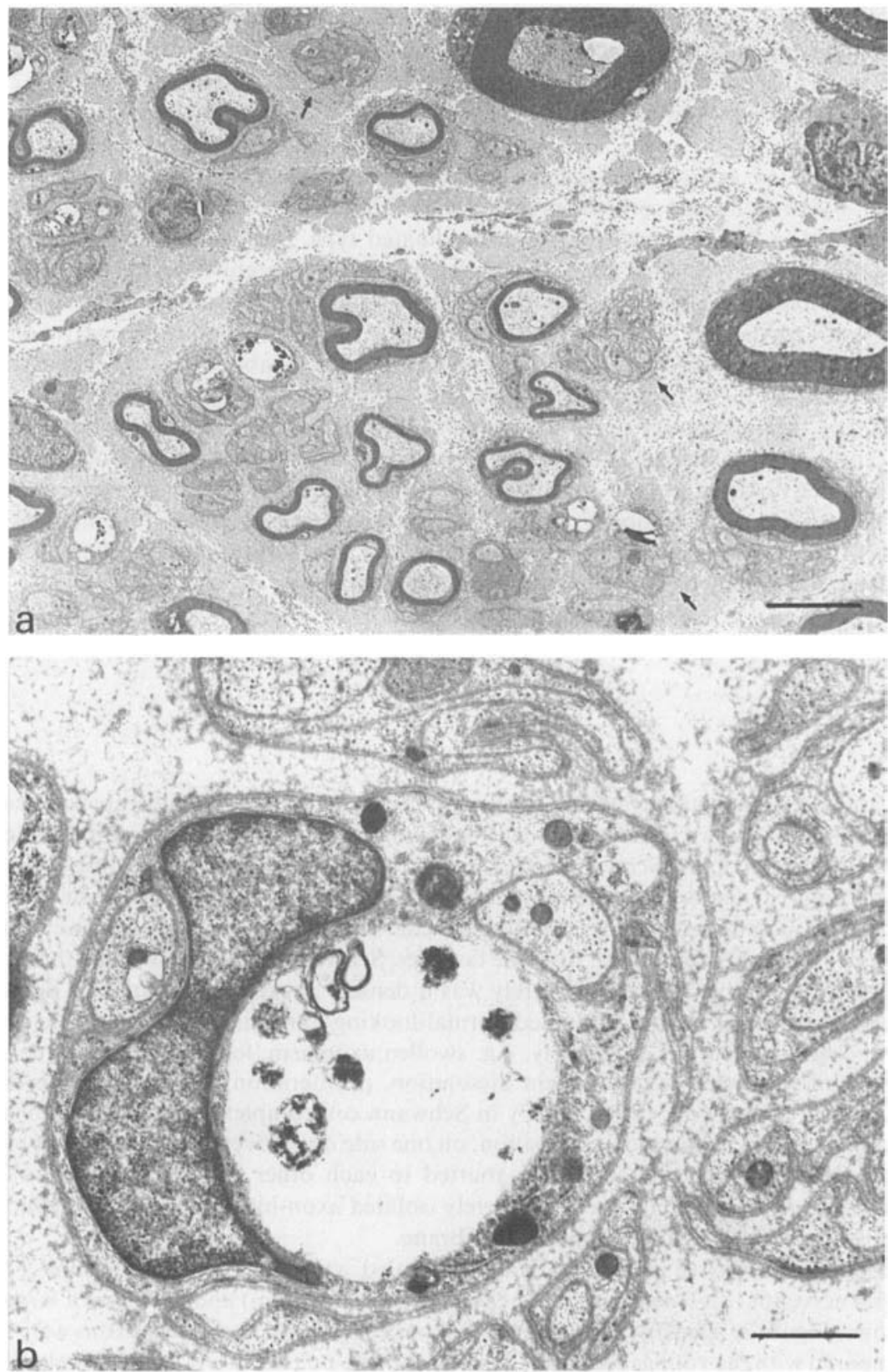

Figure 1. (a) Representative endoneurial area of case 1. Note phagosomes with bacterial structures in Schwann cell complexes associated to unmyelinated fibres and the presence of Schwann cell complexes of the myelinated type, now harbouring only unmyelinated axons $(\uparrow)$. (b) Bacterial remnants lying free in Schwann cell cytoplasm. Case 1. Bars (a) $5 \mu \mathrm{m}$; (b) $1 \mu \mathrm{m}$. 

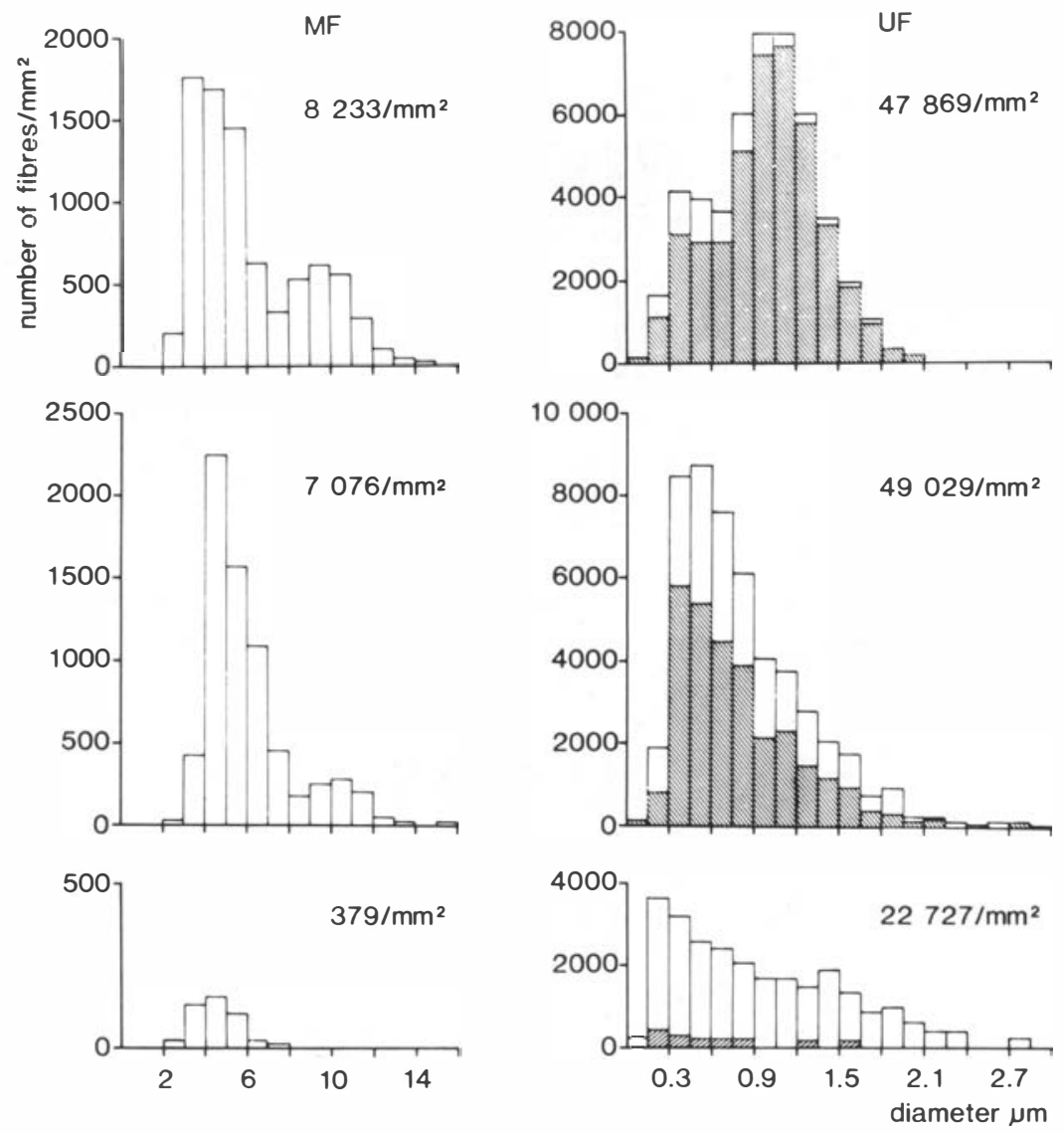

Figure 2. Histograms of (left) myelinated fibres (MF) and (right) unmyelinated fibres (UF) with respective total densities per $\mathrm{mm}^{2}$ endoneurial area. Above, control; middle, case 1; below, case 2. Grey areas of the columns represent number of UF in Schwann cell complexes of the unmyelinated type, light areas in those of unquestionable myelinated type.

axons in Schwann cells of the unmyelinated type (1.4\%; control $0.5 \%)$ did not definitively exceed normal values. ${ }^{19}$ A slight increase of denervated Schwann cell complexes of the unmyelinated type $\left(5444 / \mathrm{mm}^{2}\right)$--compared to age-matched controls of the literature $\left(3700 / \mathrm{mm}^{2}\right)^{21}$-was compatible with a mild but, considering the enlargement of endoneurial area in our case, definite loss of original unmyelinated fibres. The ratio between the corrected densities of unmyelinated and myelinated fibres was near normal ${ }^{21}$ and therefore did not indicate a preferential loss of genuine unmyelinated fibres (Table 2). There was no disproportionate increase in Schwann cell nuclei of the unmyelinated type: $71 \%$ compared to $88 \%$ in age-related control of the literature. ${ }^{21}$

\section{CASE 2}

Semithin and ultrathin sections exhibited a severe reduction of the endoneurial parenchyme and an increase of collagen masses (Figure 3 ). The heavily decreased myelinated fibres were constantly 
Table 2. Results of morphometric analysis of unmyelinated fibres with corrections according to Ochoa and Mair. ${ }^{22}$ For details see text. (UF, unmyelinated fibres; MF, myelinated fibres.)

\begin{tabular}{|c|c|c|c|c|c|c|c|c|c|c|c|}
\hline & $\begin{array}{c}\text { Area } \\
\text { evaluated } \\
\left(\mathrm{mm}^{2}\right)\end{array}$ & $\begin{array}{l}\text { Total } \\
\text { count } \\
\text { of UF }\end{array}$ & $\begin{array}{c}\text { Density } \\
\text { per } \mathrm{mm}^{2}\end{array}$ & $\begin{array}{c}\text { Number } \\
\text { per } \\
\text { nerve }\end{array}$ & Count & $\begin{array}{c}\text { Density } \\
\text { per } \mathrm{mm}^{2}\end{array}$ & $\begin{array}{l}\text { Number } \\
\text { per nerve }\end{array}$ & Count & $\begin{array}{l}\text { Density } \\
\text { per } \mathrm{mm}^{2}\end{array}$ & $\begin{array}{l}\text { Number } \\
\text { per nerve }\end{array}$ & $\begin{array}{c}\text { Ratio } \\
\text { correctec } \\
\text { densities } \\
\text { UF/MF }\end{array}$ \\
\hline Case 1 & 0.0339 & 1666 & 49,029 & 47,229 & $\begin{array}{l}1389^{*} \\
1052 \dagger\end{array}$ & $\begin{array}{l}40,877^{*} \\
30,959 \dagger\end{array}$ & $\begin{array}{l}39,376^{*} \\
29,822 \dagger\end{array}$ & $\begin{array}{l}915^{*} \\
684 \dagger\end{array}$ & $\begin{array}{l}26,927^{*} \\
20,129 \dagger\end{array}$ & $\begin{array}{l}25,939^{*} \\
19,390 \dagger\end{array}$ & $\begin{array}{l}4 \cdot 1 / 1^{*} \\
3 \cdot 1 / 1 \dagger\end{array}$ \\
\hline
\end{tabular}

* Correction by subtraction of UF in Schwann cell complexes of MF-type.

$\dagger$ Of questionable MF-type; n.d. = not done. 

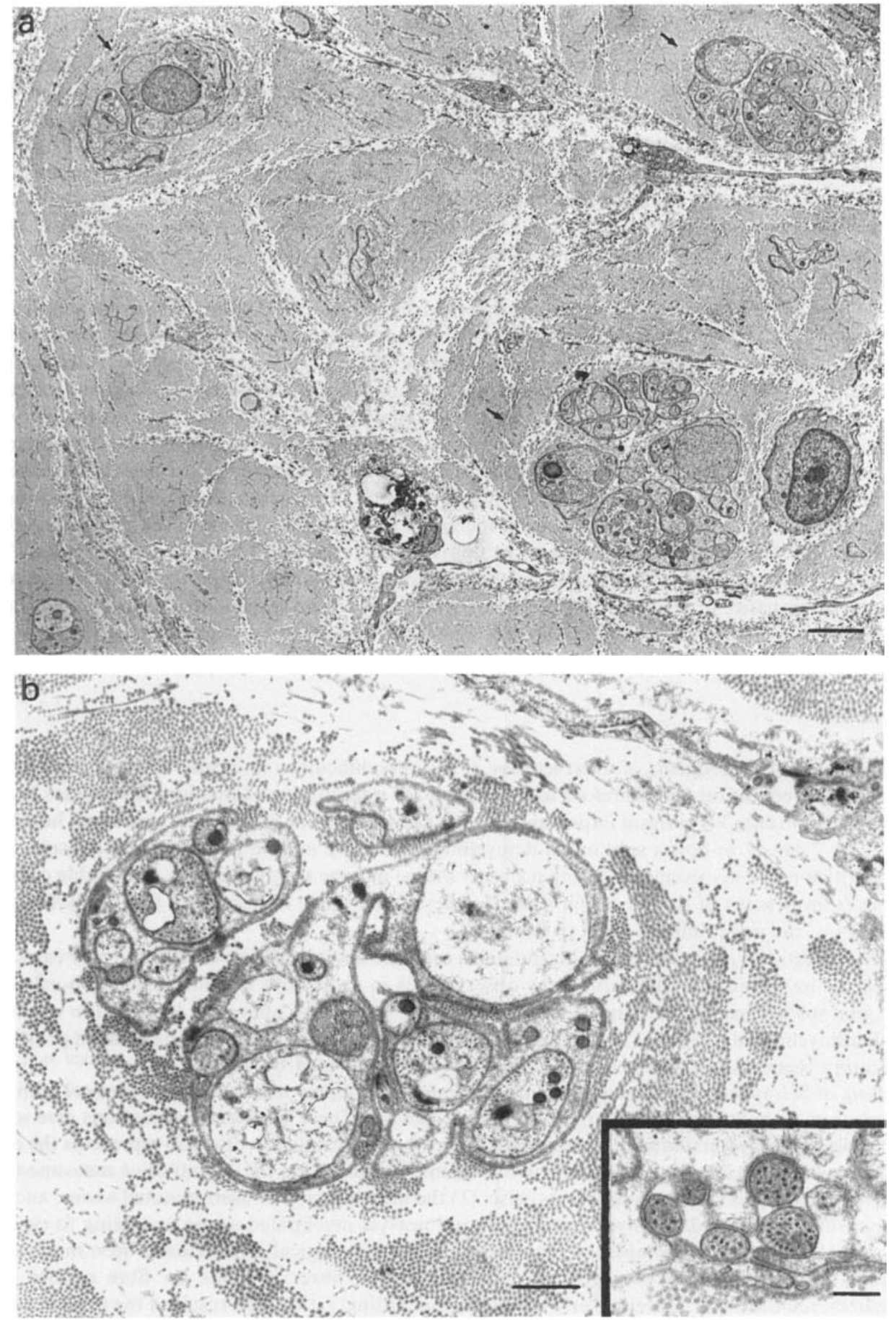

Figure 3. (a) Representative endoneurial area of case 2 in respect to unmyelinated fibres. Severe reduction of parenchyme, the majority of residual Schwann cell complexes are of the myelinated type $(\uparrow)$. Schwann cell complexes of the unmyelinated type are scanty and mostly devoid of axons. (b) Typical Schwann cell complex of the myelinated type. Note regressive alterations of some unmyelinated axons, the presence of miniature axons, abnormal location of axons, and incomplete wrapping by Schwann cell processes (inset). Case 2. Bars (a) $3 \mu \mathrm{m}$, (b) $1 \mu \mathrm{m}$, inset $0.3 \mu \mathrm{m}$. 
small and thinly remyelinated. Bacterial remnants in Schwann cells-here mostly as lysosomal residual bodies - and in some scattered macrophages were only present in moderate number. The majority of unmyelinated axons were found in Schwann cell complexes of the myelinated type (Figure 3(a) and (b)). There were many Schwann cell complexes of either type devoid of axons. On the other hand the normal ratio of about 1:1.5 between Schwann cell complexes and associated unmyelinated axons ${ }^{21,23}$ was often decreased, reaching values between $1: 11$ and $1: 17$. Qualitative alterations of unmyelinated axons and their Schwann cells were similar to those in case 1 but more numerous (Figure 3(b)). In three instances bacteria-like degraded electron dense material was seen inside degenerating unmyelinated axons.

Quantitative evaluation revealed severely reduced density $/ \mathrm{mm}^{2}$ (379) and number per nerve (454) of myelinated fibres. Unmyelinated axons exhibited a still normal total density $/ \mathrm{mm}^{2}$ and number per nerve (Table 2) when compared with our control of similar age and respective values of the literature. ${ }^{19,21}$ However, the histogram impressively demonstrates the increase of smaller diameters and the high incidence of unmyelinated axons associated to Schwann cells of the myelinated type, including the presence of obviously demyelinated or regenerating not-yet-myelinated large axons (Figure 2). Accordingly, after the correction the density $/ \mathrm{mm}^{2}$ and number per nerve of presumed original unmyelinated fibres were extremely low (Table 2). The percentage of degenerating axons in Schwann cells of the unmyelinated type was increased to $38 \%$. There was a relatively high number of denervated Schwann cell complexes of the unmyelinated type $\left(572 / \mathrm{mm}^{2}\right)$. The ratio between the corrected densities of unmyelinated and myelinated fibres was even increased (Table 2), suggesting a slight predominance of myelinated fibre loss. There was no disproportionate increase in Schwann cell nuclei of the unmyelinated type $(27 \%)$ compared to the control of similar age $(66 \%)$.

\section{Discussion}

Considering the prerequisits of overt leprosy, it is surely difficult to find cases without any further pathological condition and therefore ideally suited for quantitative evaluation. But as lues latens seropositiva in case 1 is without importance for the nervous system, and chronic persistent hepatitis $\mathrm{B}$ in case 2 causes at best a subliminal demyelination, ${ }^{25}$ there is little probability of considerable competitive nerve involvement. Another disadvantage may be seen in the lack of suitable control values from persons of similar origin. But considering the range of respective data available, this may be not the most difficult point in this study.

The qualitative alterations of unmyelinated axons and associated Schwann cells in our cases, all unspecific in nature, paralleled previous observations in cases with lepromatous and borderline

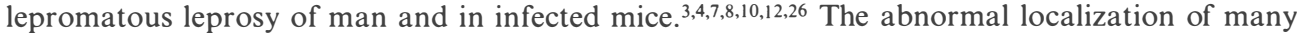
small unmyelinated axons has been already demonstrated. ${ }^{11}$ Comparable findings - most probably indicating regeneration - have been described and/or illustrated by various authors. ${ }^{23,27-30}$ Focal swelling of Schwann cells - presumably of toxic-inf ective origin - may be in part identical with the description of 'bulky' or 'hypertrophic' Schwann cells. ${ }^{15,26}$ These qualitative alterations give some hint towards unmyelinated fibre damage, but currently, quantitative evaluation represents the only reliable method to inquire about their involvement. ${ }^{23}$ Concerning the quantitative assessment of unmyelinated fibres two main problems arise: (1) the identification of unmyelinated axons; and (2) the classification in 'real' unmyelinated fibres and not-yet-myelinated axons according to type of associated Schwann cell complexes. The respective morphological criteria have been mentioned initially. The recognition of regenerating unmyelinated fibres depends on fibre calibre and numerical relations (see Materials and methods). Accordingly, the main result of the present study is the quantitative confirmation of involvement of unmyelinated fibres in lepromatous leprosy.

In case 1 with the slightest degree of functional impairment we noted a high number of unmyelinated axons. An increase has been suspected by Dastur et al..$^{15}$ in early stages of lepromatous leprosy and is known from other polyneuropathies as well, ${ }^{19,20,23}$ suggesting 
regeneration after primary degeneration. The tentative correction of unmyelinated fibres by subtraction of all obviously nongenuine ones could not confirm a clear cut pathological reduction of original unmyelinated fibres. Fibre loss was only deducible from a slight increase in denervated Schwann cell complexes ${ }^{19-21,23}$ and the abnormal left-shifted histogram, reflecting the high part of regenerating unmyelinated fibres and confirming the observation of Dastur \& Porwal, ${ }^{4}$ who were impressed by clusters of very small unmyelinated axons in an otherwise slightly affected leprosy nerve. The marked peak of $0 \cdot 3-0 \cdot 6 \mu$ m diameter fibres obviously comprises a considerable amount of not-yet-myelinated axons deducible from the type of associated Schwann cells, thus indicating a marked primary loss of myelinated fibres as well, not expected by their mere quantitative assessment.

In case 2 with an advanced stage of lepromatous leprosy and moderate sensory-motor polyneuropathy the number of unmyelinated axons is likewise still in normal range for this age group. However, their high incidence in Schwann cells of the myelinated type reflects the large amount of not-yet-myelinated axons after previous Wallerian degeneration and segmental demyelination of myelinated fibres. Accordingly, the corrected values for original unmyelinated fibres are unequivocally severely reduced. Damage and loss of unmyelinated fibres are indicated by the relatively high presence of degenerating unmyelinated axons and of denervated Schwann cell complexes of the unmyelinated type as well. Presumably frustrane regeneration may be derived from the occurrence of Schwann cell complexes harbouring numerous (up to 17) unmyelinated axons.

In both cases the ratio between the presumably original populations of unmyelinated and myelinated fibres could not support a predominant involvement of unmyelinated fibres, although according to various observations in man and mice the earliest cells to harbour bacilli are Schwann cells associated with unmyelinated fibres and the earliest lesions were observed in unmyelinated fibres and their Schwann cells. ${ }^{2,9,11,12}$ Apparently, involvement of myelinated fibres, especially smaller calibres ${ }^{11}$ which likewise conduct pain and thermal sensibility, will soon follow and quickly reach an equal (case 1) or even higher degree (case 2).

Viable bacteria and granular bacterial remnants were common in case 1 with the shortest previous systematical treatment. They were preferentially located in Schwann cells of the unmyelinated type as already stressed by others. ${ }^{2-4,8,15,31,32}$ There seems to be a tendency to more membrane-bound residual structures - typical phagosomes - in our treated case 1 when compared to the illustrations of the literature concerning untreated cases. Moreover, phagosomes obviously exhibited electron dense membranes more often, especially when harbouring bacterial remnants with advanced degeneration, as also underlined by Job. ${ }^{33}$ In our case 2, who has been treated for several months, bacterial remnants were scarce and mostly more severely degraded. Bacterial remnants in unmyelinated axons, observed by some authors ${ }^{5,9,32,34}$ were seen only in case 2 in rare instances. Therefore, bacterial spread via unmyelinated axons may be of minor importance in the pathogenesis of lepromatous leprosy.

\section{Acknowledgments}

We are indebted to Dr F Behse, Berlin, for intensive discussion of the manuscript. The technical assistance of Mrs M Kentenich and Mrs E Tas is gratefully acknowledged.

\section{References}

${ }^{1}$ Boyle A, Ramu G. Assessment of cutaneous autonomic nerve functions in leprosy. Lepr India, 1982; 54: 51824.

2 Antia NH, Shetty VP, Mehta LN. Study of evolution of nervedamage in leprosy. Le pr India, 1980; 52: 48-52. 
${ }^{3}$ Boddingius J. Ultrastructural changes in blood vessels of peripheral nerves in leprosy neuropathy. Acta neuropath (Berl.), 1976; 35: 159-81.

4 Dastur DK, Porwal GL. Lepromatous leprosy as a model of Schwann cell pathology and lysosomal activity. Clin exp Neurol, 1979; 16: 277-93.

${ }^{5}$ Imaeda T, Convit J. Electron microscope study of cutaneous nerves in leprosy. Int J Leprosy 1963; 13: 188210.

6 Job CK. Mechanism of nerve destruction in tuberculoid-borderline leprosy. J neurol Sci, 1973; 20: 25-38.

${ }^{7}$ Mehta LN, Shetty VP, Antia NH, Irani PF. Quantitative, histologic and ultrastructural studies of the index branch of the radial cutaneous nerve in leprosy and its correlation with electrophysiologic study. Int $J$ Leprosy, 1975; 43: 256-64.

8 Shetty VP, Mehta LN, Irani PF, Antia NH. Study of the evolution of nerve damage in leprosy. Lepr India, 1980; 52: 5-18.

9 Yoshizumi MO, Asbury AK. Intra-axonal bacilli in lepromatous leprosy. Acta neuropath (Berl.), 1974; 27: 110.

10 Shetty VP, Antia NH. Myelination around multiple axons in the peripheral nerve. Acta neuropath (Berl.), 1980; 50: 147-51.

11 Shetty VP, Antia NH. Degeneration and regeneration of unmyelinated fibers in experimental leprous neuropathy. Int $J$ Leprosy, 1981; 49: 324-30.

12 Shetty VP, Vidyasagar PB, Antia NH. Study of evolution of nerve damage in leprosy. Le pr India, 1980; 52: 26-47.

13 Antia NH, Mehta L, Shetty V, Irani PF. Clinical, electrophysiological, quantitative, histologic and ultrastructural studies of the index branch of the radial cutaneous nerve in leprosy. Int J Leprosy, 1975; 43: 106-13.

14 Job CK. Pathology of peripheral nerve lesions in lepromatous leprosy. Int J Leprosy, 1971; 39: 251-68.

15 Dastur DK, Ramamohan Y, Shah JS. Ultrastructure of lepromatous nerves. Int J Leprosy, 1973; 41: 47-80.

16 Job CK, Victor DBI, Chacko CJG. Progressive nerve lesion in a disease-arrested leprosy patient. Int $J$ Leprosy, 1977; 45: 255-60.

17 Gibbels E, Henke U, Klingmüller G, Haupt WF. Myelinated and unmyelinated fibers in sural nerve biopsy of a case with lepromatous leprosy - a quantitative approach. Int $J$ Leprosy, 1987; 55: 333-37.

18 Gibbels E, Schaefer HE, Runne U, Schröder JM, Haupt WF, Assmann G. Severe polyneuropathy in Tangier disease mimicking syringomyelia or leprosy. J Neurol, 1985; 232: 283-94.

19 Behse F, Buchthal F, Carlsen F, Knappeis GG. Unmyelinated fibres and Schwann cells of sural nerve in neuropathy. Brain, 1975; 98: 493-510.

${ }^{20}$ Schröder JM, Gibbels E. Marklose Nervenfasern im Senium und im Spätstadium der ThalidomidPolyneuropathie. Acta neuropath (Berl.), 1977; 39: 271-80.

${ }^{21}$ Ochoa J, Mair WGP. The normal sural nerve in man. II. Changes in the axons and Schwann cells due to ageing. Acta neuropath (Berl.), 1969; 13: 217-39.

22 Gibbels E, Henke U, Klingmüller G. Unmyelinated nerve fibers in sural nerve biopsis of lepromatous leprosy (Abstract). Clin Neuropathol, 1986; 5: 103

23 Ochoa J. Recognition of unmyelinated fiber disease: morphologic criteria. Muscle \& Nerve, 1978; 1: $375-87$.

${ }^{24}$ Dyck PJ, Lambert EH, Nichols PC. Quantitative measurement of sensation related to compound action potential and number and sizes of myelinated and unmyelinated fiber of sural nerve in health, Friedreich's ataxia, hereditary sensory neuropathy, and tabes dorsalis. In: Handbook of electroencephalography and clinical neurophysiology. Vol 9, Remond A (ed.). Amsterdam: Elsevier Publ Co, 1971, pp. 83-118.

25 Asbury AK. Hepatic neuropathy. In: Peripheral Neuropathy, Vol II, Dyck PJ, Thomas PK, Lambert EH, Bunge R (eds). Philadelphia: WB Saunders Comp, 1984, pp. 1826-32.

26 Job CK, Verghese R. Schwann cell changes in lepromatous leprosy. Indian J med Res, 1975; 63: 897-901.

27 Bray GM, Peyronnard JM, Aguayo AJ. Reactions of unmyelinated nerve fibers to injury. An ultrastructural study. Brain Res 1972; 42: 297-309.

28 Thomas PK, King RHM. The degeneration of unmyelinated axons following nerve section: an ultrastructural study. J Neurocytol, 1974; 3: 497-512.

${ }^{29}$ Fowler TJ, Ochoa J. Unmyelinated fibres in normal and compressed peripheral nerves of the baboon: a quantitative electron microscopic study. Neuropathol appl Neurobiol, 1975; 1: 247-65.

30 Brown MJ, Martin JR, Asbury AK. Painful diabetic neuropathy. Arch Neurol, 1976; 33, 164-71.

31 Balentine JD, Chang SC, Issar SL. Infection of armadillos with mycobacterium leprae. Arch Pathol Lab Med, 1976; 100: 175-81.

32 Boddingius $\mathrm{J}$. The occurrence of Mycobacterium leprae within axons of peripheral nerves. Acta neuropath (Berl.), 1974; 27: 257-70.

33 Job CK. Mycobacterium leprae in nerve lesions in lepromatous leprosy. Arch Pathol, 1970; 89: 195-207.

34 Boddingius J. Ultrastructural changes in blood vessels of peripheral nerves in leprosy neuropathy. Acta neuropath (Berl.), 1977; 40: 21-39. 